\title{
Transformation of Micrococcus lysodeikticus by Various Members of the Family Micrococcaceae
}

\author{
By W. E. KLOOS \\ Department of Genetics, \\ North Carolina State University, Raleigh, \\ North Carolina 27607, U.S.A. \\ (Accepted for publication 29 August 1969)
}

\begin{abstract}
SUMMARY
Various strains originally designated as members of the genera Micrococcus, Sarcina, and Staphylococcus were able to transform adenine, histidine, and tryptophan auxotrophs of Micrococcus lysodeikticus to prototrophy at relatively high frequencies. These included certain strains of $M$. flavocyaneus, $M$. flavus, M. luteus, $M$. lysodeikticus, $M$. sodonensis, Sarcina flava, S. lutea, S. subflava, Staphylococcus afermentans and St.flavocyaneus. Many of the above strains were adenine auxotrophs and produced low frequencies of prototrophic recombinants when crossed with the adenine-dependent $M$. lysodeikticus strain ISU. Prototrophic strains of $M$. conglomeratus, $M$. radiodurans, $M$.roseus, M.rubens, M. varians, St. aureus and St. epidermidis failed to transform $M$. lysodeikticus in these studies. Prototrophic pigment mutants of $M$. lysodeikticus and $S$. lutea were able to doubly transform yellow auxotrophs of $M$. lysodeikticus to prototrophy and donor colour.
\end{abstract}

\section{INTRODUCTION}

The taxonomic status of the 'species' Micrococcus lysodeikticus, isolated by Fleming (I922), has been under investigation for a number of years. One significant step toward classification was made when Evans, Bradford \& Niven (1955) proposed including this organism in the genus Micrococcus and separating it from the staphylococci on the basis of its relation to oxygen (obligate aerobe) in a standardized complex medium containing glucose. As a result of numerous physiological and biochemical studies, Kocur \& Martinec (I962, I963, I965) and Rosypal \& Kocur (1963) have suggested that strains of $M$. lysodeikticus be included together with certain strains of $M$. cyaneus, $M$. flavocyaneus, M. flavus, M. luteus, M. sodonensis, Sarcina aurantiaca, S. citrea, S. flava, S. lutea, S. marginata, S. pelagia, S. subflava, S. variabilis, Staphylococcus afermentans, and St. flavocyaneus into a single species, M. luteus. Baird-Parker (1963, I965) also combined $M$. lysodeikticus with representatives of the above organisms into a single taxonomic group, Micrococcus subgroup 7. More recent studies by Rosypal, Rosypalova \& Horejs (I966), based on DNA base composition and Adansonian analysis, have shown that most of the strains classified as M. luteus by Kocur \& Martinec possessed high coefficients of similarity (S value) and had approximately similar GC contents in their DNA. However, they proposed subdividing these micrococci on the basis of DNA base ratios: group I ( $M$. flavocyaneus, $M$. flavus, $M$. lysodeikticus, M. sodonensis, S. citrea, S. flava, S. lutea, S. marginata, S. pelagia, $S$. 
subflava, S. variabilis, St. afermentans, and St. flavocyaneus) having 70.8 to $73.3 \%$ GC; group 2 (S. aurantiaca and several other micrococci) having 67.5 to $69.5 \% \mathrm{GC}$; and group 3 ( $M$. luteus strain ATCC 398 and $M$. cyaneus) having 65.8 to $67.0 \%$ GC.

Preliminary studies on transformation in Micrococcus lysodeikticus (Kloos \&

Table I. Transformation of nutritional markers in Micrococcus lysodeikticus by various members of the family Micrococcaceae

Prototrophs $/ 10^{6}$ colonyforming units resulting in crosses with $M$.

Nutritional classification lysodeikticus strain ISU including mutant or Donor species* Strain Source $†$ auxotrophic genotype $\overbrace{\text { ade }{ }_{\text {trpE } \mathrm{I} 6 \text { hisD }} 6 \mathrm{I}}^{\text {auxotrophs }}$

Micrococcus

$M$. candican

M. citreus ATCC 8456 $\operatorname{ATCC} 395$

M. conglomeratus

$M$. flavocyaneus

M. flavocyaneus

ATCC 401

M. flavocyaneus

8673

СCM 622

CCM $85 \mathrm{I}$

M. flavocyaneus

CCM 853

M. flavus

ATCC 400

M. flavus

ATCC 10240

$M$. luteus

$M$. luteus

ATCC 398

$M$. luteus

CCMIO5

-
-
+
ade
ade
ade
ade

ade

ade

$+$

ade

ade $^{+-I}$

CCM 308

$M$. luteus

CCM 355

$M$. luteus

$M$. luteus

CCM 370

CCM 408

$+$

ade

ade

$M$. luteus

CCM I 423

M. luteus

CCM I 672

$+$

ade

M. lysodeikticus ISU

\section{ade $^{+}-1$}

ade

ade $^{+}-\mathrm{I}$

ade ${ }^{+}$I $\operatorname{trp} E$ I 6

$a^{+}{ }^{+}$I hisD 6I

M. lysodeikticus
$M$. lysodeikticus
M. lysodeikticus
M. lysodeikticus
$M$. lysodeikticus
M. lysodeikticus
$M$. radiodurans
$M$. roseus
$M$. roseus
$M$. roseus
$M$. roseus
$M$. roseus
$M$. roseus
$M$. rubens
$M$. sodonensis
$M$. varians

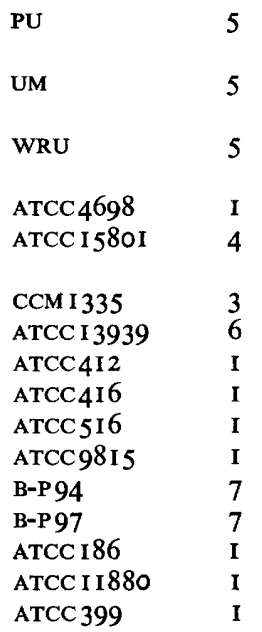

ade

ade $^{+-8}$

ade

ade $^{+-\mathrm{I}}$

ade

ade $^{+}-\mathrm{I}$

ade

ade

ade $^{+}-4$

$+$

$+$

$<I<I<$

$\begin{array}{lll}<\mathrm{I} & <\mathrm{I} & <\mathrm{I}\end{array}$

$26 \quad 888 \quad 283$

IO $530 \quad$ I 26

$\begin{array}{lll}12 & 572 & 13 \mathrm{I}\end{array}$

$297 \quad$ I $279 \quad 348$

I6 6I3 I72

$\begin{array}{lll}9 & 238 & 82\end{array}$

$192 \quad 470 \quad I 74$

$<$ I $<$ I $<$ I

II II $\quad 27$ I

$\begin{array}{lll}340 & 1279 & 230 \\ 220 & 1080 & 210\end{array}$

$234 \quad 760 \quad 179$

$8 \quad 852 \quad$ I4O

$\begin{array}{rrr}8 & 852 & 140 \\ 23 & 1088 & 96\end{array}$

4I4 $1236 \quad 74$

$696 \quad 665 \quad 263$

$32 \quad 1390 \quad 260$

$\begin{array}{lll}374 & 1240 & 188\end{array}$

$\begin{array}{lll}<I & I I 76 \quad 478\end{array}$

$\begin{array}{lll}346 & 1899 & 232\end{array}$

$563<$ I 190

$548 \quad 1260<$ I

$\begin{array}{lll}34 & 2394 & 227\end{array}$

$374 \quad 2 I 26 \quad 307$

I I I I I 203

261 IOI3 180

$\begin{array}{lll}9 & I 8 I 2 & I 98\end{array}$

$\begin{array}{lll}381 & 1762 & 186\end{array}$

$9 \quad 2046 \quad 350$

$\begin{array}{lll}16 & 784 & 102\end{array}$

$\begin{array}{lll}338 & 627 & \text { II } 8\end{array}$

$276 \quad 967 \quad$ I5I

$<$ I $<$ I $<$ I

$<$ I $<$ I $<$ I

$<$ I $<$ I $<$ I

$<$ I $<$ I $<$ I

$<$ I $<$ I $<$ I

$<$ I $<$ I $<$ I

$<$ I $<$ I $<$ I

$<$ I $<$ I $<$ I

$264 \quad 935 \quad 217$

$<$ I $<$ I $<$ I 
Table I cont.

\begin{tabular}{|c|c|c|c|c|c|c|}
\hline \multirow[b]{2}{*}{ Donor species* } & \multirow[b]{2}{*}{ Strain } & \multirow[b]{2}{*}{ Source $\dagger$} & \multirow{2}{*}{$\begin{array}{l}\text { Nutritional classification } \\
\text { including mutant or } \\
\text { auxotrophic genotype } \ddagger\end{array}$} & \multicolumn{3}{|c|}{$\begin{array}{l}\text { Prototrophs } / \mathrm{IO}^{6} \text { colony- } \\
\text { forming units resulting } \\
\text { in crosses with } M \text {. } \\
\text { lysodeikticus strain ISU } \\
\text { auxotrophs } \$\end{array}$} \\
\hline & & & & ade & $\operatorname{trp} E_{\mathrm{I}} 6$ & hisD 6I \\
\hline \multicolumn{7}{|l|}{ Sarcina } \\
\hline S. aurantiaca & ATCC I 46 & 4 & - & $<\mathrm{I}$ & $<\mathrm{I}$ & $<\mathrm{I}$ \\
\hline S. flava & ATCC 540 & 4 & ade & 24 & 972 & 162 \\
\hline S. lutea & ATCC 272 & 3 & + & 235 & 708 & 359 \\
\hline S. lutea & ATCC $38 \mathbf{I}$ & 4 & ade & 17 & 512 & 163 \\
\hline S. lutea & ATCC 382 & 2 & $(-)$ & 500 & 638 & 190 \\
\hline S. lutea & ATCC 533 & 8 & + & 325 & 1479 & $16 I$ \\
\hline S. subflava & ATCC 7468 & 4 & + & 240 & 855 & 320 \\
\hline S. ureae & ATCC 6473 & 4 & - & $<\mathrm{I}$ & $<\mathrm{I}$ & $<\mathrm{I}$ \\
\hline S. ureae & NCDO I 548 & 9 & - & $<\mathrm{I}$ & $<\mathrm{I}$ & $<\mathrm{I}$ \\
\hline \multicolumn{7}{|l|}{ Staphylococcus } \\
\hline St. afermentans & ATCC 15307 & 4 & + & 806 & 2568 & 204 \\
\hline St. aureus & 655 & 10 & $(+)$ & $<\mathrm{I}$ & $<\mathrm{I}$ & $<\mathrm{I}$ \\
\hline St. aureus & 83 & ro & $(+)$ & $<\mathrm{I}$ & $<\mathrm{I}$ & $<\mathrm{I}$ \\
\hline St. epidermidis & B-P 287 & 7 & $(+)$ & $<\mathrm{I}$ & $<\mathrm{I}$ & $<\mathrm{I}$ \\
\hline St. epidermidis & B-P2 2 & 7 & $(+)$ & $<\mathrm{I}$ & $<\mathrm{I}$ & $<\mathrm{I}$ \\
\hline St. epidermidis & B-P I 2 & 7 & $(+)$ & $<\mathrm{I}$ & $<\mathrm{I}$ & $<\mathrm{I}$ \\
\hline St. epidermidis & B-P 2I & 7 & $(+)$ & $<\mathrm{I}$ & $<\mathrm{I}$ & $<\mathrm{I}$ \\
\hline St. epidermidis & B-P 3 I & 7 & $(+)$ & $<\mathrm{I}$ & $<\mathrm{I}$ & $<\mathrm{I}$ \\
\hline St. flavocyaneus & CCM 247 & 3 & ade & I8 & $64 \mathrm{I}$ & $22 \mathrm{I}$ \\
\hline
\end{tabular}

* Strains which were originally designated Micrococcus flavocyaneus (сCM 622, СCM851, СCM853), M. lysodeikticus (CCM I335), Sarcina lutea (ATCC272), and Staphylococcus flavocyaneus (CCM 247) were received from M. Kocur as strains of $M$. luteus (Kocur \& Martinec, I962; I963).

$\dagger$ I-J. B. Evans, North Carolina State Univ., Raleigh, N.C., U.S.A.; 2-E. R. Kennedy, Catholic Univ., Washington, D.C., U.S.A.; 3-M. Kocur, Czechoslovak Collection of Microorganisms, J. E. Purkyne Univ., Brno, CSSR; 4-American Type Culture Collection, Rockville, Maryland, U.S.A.; 5-E. A. Grula, Oklahoma State Univ., Stillwater, Okla., U.S.A.; 6-A. H. Schein, Univ. of Vermont, Burlington, Vermont, U.S.A.; 7-A. C. Baird-Parker, Unilever Research Laboratory, Bedford, England; 8-T. Tornabene, Colorado State Univ., Fort Collins, Colo., U.S.A.; 9-E. I. Garvie, National Collection of Dairy Organisms, Univ. of Reading, Reading, England; Io-P. A. Pattee, Iowa State Univ., Ames, Iowa, U.S.A.

$\ddagger$ ade = Adenine requirement (growth stimulated by adenine, adenosine, inosine, or hypoxanthine); $a^{+}=$adenine-independent mutant, notation followed by arabic numeral to indicate order of isolation, e.g. $a d e^{+-1} ; \operatorname{trp} E$ I6 $=$ L-tryptophan requirement (growth stimulated by anthranilic acid, indole, or L-tryptophan); hisD 6I $=$ L-histidine requirement (growth stimulated by L-histidine but not by L-histidinol); - = no detectable growth (colonies) on defined agar, phenotype unclassified; $(-)=$ no detectable growth on defined agar, but genotype is believed to be $a p e^{+} t r p E^{+} h i s D^{+}$based on transformation data; $(+)=$ no detectable growth on defined agar of Kloos \& Schultes (1969), but prototrophic phenotype classified on defined agar for staphylococci of Kloos \& Pattee (1965); $+=$ prototroph.

$\S$ Data represent the average of two separate DNA preparations. Two crosses were made from each preparation and each cross plated on duplicate plates. Recipient controls without DNA produced $<$ I prototroph $/ 10^{6}$ colony-forming units.

Schultes, 1969) have shown that Sarcina lutea strain ATCC272 was able to transform adenine auxotrophs of certain M.lysodeikticus strains to prototrophy, providing evidence of close genetic relationship. Extending transformation studies between $M$. lysodeikticus and other members of the family Micrococcaceae would offer the possibility of examining genetic exchange among these organisms and would broaden our understanding of a genetic definition of Micrococcus species, i.e. those micrococci 
that can potentially contribute to, or share in, a common gene pool (Marmur, Falkow \& Mandel, I963). In this investigation, various Micrococcaceae have been tested for transforming activity of nutritional markers in crosses with the high transformation frequency M. lysodeikticus strain ISU (Kloos, I969; Kloos \& Schultes, I969). In addition, preliminary studies on transformation of pigment markers is reported.

\section{METHODS}

Bacterial strains. Donor strains selected for this study were originally designated as members of the genera Micrococcus, Sarcina and Staphylococcus and were, in particular, those sensitive to either lysozyme or lysostaphin (Table I).

Cultures received by this laboratory were checked for purity and to some extent proper identification by (I) colony morphology and pigment production on a complex agar medium (P agar) (Naylor \& Burgi, I956) incubated at 26 and $34^{\circ}$ and (2) microscopic examination of Gram-stained cells. Each strain was also tested for prototrophy, with respect to adenine, L-tryptophan, and L-histidine, by examining colony formation on a defined agar medium (Kloos \& Schultes, I969) incubated at 26 and $34^{\circ}$. Strains which failed to produce detectable colonies or colonies of less than $0.1 \mathrm{~mm}$. diameter by 8 days were further tested for adenine, L-tryptophan, and/or L-histidine auxotrophy on defined agar media supplemented with each metabolite $(20 \mu \mathrm{g} . / \mathrm{ml}$. $)$ singly or in combinations.

\section{Table 2. Double transformation of pigment and nutritional markers in Micrococcus lysodeikticus}

\begin{tabular}{|c|c|c|c|c|c|}
\hline \multirow[b]{2}{*}{$\begin{array}{l}\text { Prototrophic } \\
\text { donor species }\end{array}$} & \multirow[b]{2}{*}{ Strain } & \multirow[b]{2}{*}{$\begin{array}{l}\text { Pigment } \\
\text { genotype* }\end{array}$} & \multicolumn{3}{|c|}{$\begin{array}{l}\text { Donor pigment-prototrophs } / \mathrm{IO}^{6} \\
\text { colony-forming units resulting } \\
\text { in crosses with } M \text {. lysodeikticus } \\
\text { strain ISU yellow-auxotrophs }{ }^{\dagger}\end{array}$} \\
\hline & & & \multicolumn{3}{|c|}{ pig-y ade pig-y trpE $\overbrace{\mathrm{I} 6 \text { pig-y his D } 6 \mathrm{r}}$} \\
\hline \multirow[t]{3}{*}{ M. lysodeikticus } & ISU & pig-w & $I \cdot 2$ & $6 \cdot 7$ & $I \cdot O$ \\
\hline & & pig-p & $I \cdot 9$ & $7 \cdot 3$ & $I \cdot 5$ \\
\hline & & pig-o & 0.9 & 5.0 & 0.8 \\
\hline M. lysodeikticus & ATCC I $580 \mathrm{I}$ & pig-p & $r \cdot 0$ & $4^{\cdot I}$ & 0.5 \\
\hline \multirow[t]{3}{*}{ Sarcina lutea } & $\operatorname{ATCC} 272$ & pig-w & 0.6 & 2.4 & 0.4 \\
\hline & & pig-p & $I \cdot O$ & $4 \cdot 7$ & 0.4 \\
\hline & & pig-o & 0.7 & I.9 & 0.5 \\
\hline
\end{tabular}

* pig-w $=$ white $;$ pig-p = pink; pig-o = orange.

$\dagger$ Data represent the average of two separate DNA preparations. Two crosses were made from each preparation and each cross plated on ten plates. Recipient controls without DNA or DNA isolated from yellow strains produced $<0.1$ donor pigment-prototroph $/ 10^{6}$ colony-forming units.

Spontaneous adenine-independent mutants were isolated from certain adeninedependent strains and used as donors. Several different pigment mutants of Micrococcus lysodeikticus strain ISU and Sarcina lutea strain ATCC 272 were obtained by treatment of yellow strains with $N$-methyl- $N^{\prime}$-nitro- $N$-nitrosoguanidine (NTG) (300 $\mu \mathrm{g} . / \mathrm{ml}$.) (Adelberg, Mandel \& Chen, 1965) and were also used as donors (Table 2).

Recipient strains included the adenine-dependent Micrococcus lysodeikticus strain ISU and a tryptophan and histidine auxotroph derived from a spontaneous adenineindependent mutant $\left(a d e^{+}-\mathrm{I}\right)$ of this strain by treatment with NTG (Table I). The tryptophan and histidine auxotrophs were biochemically characterized by growth 
stimulation studies and chromatographic analysis of de-repressed culture supernatants (Kloos \& Pattee, 1965; Rose \& Kloos, I969).

Procedure for DNA isolation. Staphylococcus aureus and St. epidermidis strains were grown in tryptic soy broth (Difco) at $37^{\circ}$ for $18 \mathrm{hr}$. All other donor strains were grown in a glucose + yeast extract broth (Rosypalova, Bohacek \& Rosypal, I966) at $30^{\circ}$ for 18 to $24 \mathrm{hr}$. Cultures were shaken during incubation with a Burrell WristAction Shaker (Burrell Corporation, Pittsburgh, Pennsylvania) at a setting of two giving 324 shakes $/ \mathrm{min}$. through an arc of $3^{\circ}$. The yield in $100 \mathrm{ml}$. of broth was about I to $3 \mathrm{~g}$. wet packed cells. After growth, cells were harvested by centrifugation and washed twice with a NaCl-EDTA solution: $0 \cdot 15 \mathrm{M}-\mathrm{NaCl}+0 \cdot 10 \mathrm{M}$-ethylenediamine-tetraacetic acid (EDTA), pH 8.0. DNA was isolated by the procedure of Marmur (196I) with the modification of Saito \& Miura (1963) using TI ribonuclease (RNase) (Sankyo Company, Ltd., Tokyo, Japan) as well as bovine pancreatic RNase (Calbiochem, Los Angeles, California). The duration of lysozyme (Calbiochem) treatment varied from I $\mathrm{hr}$ to as long as I2 $\mathrm{hr}$ for more resistant strains. Lysostaphin (kindly supplied by Dr W. A. Zygmunt, Mead Johnson Research Centre, Evansville, Indiana) was used in place of lysozyme to lyse St. aureus strains. The final DNA fibres were sterilized in $75 \%$ ethanol for $2 \mathrm{hr}$ and then dispersed into a $\frac{1}{10}$ dilution of sterile standard saline solution (SS: $0.1 \mathrm{M}-\mathrm{NaCl}, \mathrm{pH} 77^{\circ}$ ) which was adjusted to $\mathrm{SS}$ as soon as dispersion was completed. DNA preparations were used within 2 days of isolation and were stored at $4^{\circ}$. DNA concentration was determined by the diphenylamine reaction of Dische (I955).

Procedure for transformation. An $18 \mathrm{hr} \mathrm{P}$ agar slope culture of the recipient strain was suspended in I $\mathrm{ml}$. saline and diluted $\mathrm{I} / \mathrm{IOO}$ in saline. Aliquots of $\mathrm{O} \cdot \mathrm{I} \mathrm{ml}$. (about $5 \times 10^{6}$ colony-forming units) from the diluted suspension were added to duplicate tubes containing I ml. defined broth (Kloos, I969) supplemented with Io $\mu \mathrm{g}$. $/ \mathrm{ml}$. adenine (strain ISU ade), Io $\mu \mathrm{g} . / \mathrm{ml}$. L-histidine (strain IsU ade ${ }_{-}$I hisD 6I), or I $5 \mu \mathrm{g} . / \mathrm{ml}$. L-tryptophan (strain ISU $a d e^{+}-\mathrm{I} \operatorname{trp} E$ I6). Mixtures were shaken in a $34^{\circ}$ water bath with a Burrell Wrist-Action Shaker at a setting of four giving 324 shakes/min. through an arc of $6^{\circ}$ for $\mathrm{I} 2 \mathrm{hr}$ (strain ISU ade ${ }^{+} \mathrm{I}$ hisD 61) or $24 \mathrm{hr}$ (strains ISU ade and ISU $a d e^{+}-\mathrm{I} \operatorname{trp} E \mathrm{i}$ 6). After growth, cocci (about $\mathrm{I}-3 \times 10^{8}$ colony-forming units $/ \mathrm{ml}$.) were centrifuged and resuspended in $\mathrm{I} \mathrm{ml}$. transformation buffer: $0.05 \mathrm{M}$-tris (hydroxymethyl) aminomethane (tris) $+0.0 \mathrm{I} \mathrm{M}-\mathrm{SrCl}_{2}+0.5 \%$ monosodium glutamate, $\mathrm{pH} 7 \cdot 0$. DNA (10 $\mu \mathrm{g}$. in 0.03 to $0.8 \mathrm{ml}$. SS) was added to each tube and the mixtures shaken in a $30^{\circ}$ water bath at a setting of four for $\mathrm{I} \mathrm{hr}$. Exposure to DNA was terminated by the addition of deoxyribonuclease $(5 \mu \mathrm{g}$. $/ \mathrm{ml}$.) (Worthington Biochemical Corporation, Freehold, New Jersey) and $0.005 \mathrm{M}-\mathrm{MgSO}_{4}$ with incubation at $37^{\circ}$ for $\mathrm{I} 5 \mathrm{~min}$. After treatment, cocci were centrifuged and resuspended in I ml. saline. Samples of $0.1 \mathrm{ml}$. were taken from the saline suspension, a $\mathrm{IO}^{-1}$ and $\mathrm{IO}^{-2}$ dilution in saline and spread on duplicate defined agar plates. Prototrophs were scored after incubation at $34^{\circ}$ for $72 \mathrm{hr}$. Additional plates were prepared and incubated at $26^{\circ}$ for $72 \mathrm{hr}$ in crosses where the donor strain had a more optimum growth at $26^{\circ}$ than at $34^{\circ}$. Plates failing to show significant numbers of prototrophic transformants were incubated for an additional 5 days. In crosses where pigment mutants were used as donors, pigment-prototrophs (double transformants) were scored after incubation for 6 days to allow for pronounced pigment production. 


\section{RESULTS}

Nutritional characterization of donor strains. Many of the donor strains tested were able to produce relatively large colonies $(0.5$ to $2.0 \mathrm{~mm}$. diam. in $96 \mathrm{hr})$ on the defined agar medium used in transformation experiments (Table I). These were considered prototrophic with respect to adenine, L-histidine, and L-tryptophan as these nutrients were omitted from the medium.

Some of the strains tested proved to be adenine auxotrophs and were markedly stimulated by either adenine, adenosine, inosine, or hypoxanthine. For example, auxotrophs that showed no detectable growth or colonies less than $0.1 \mathrm{~mm}$. diam. (leaky strains) on defined agar media produced colonies of 0.5 to $\mathrm{I} .6 \mathrm{~mm}$. diam. in $96 \mathrm{hr}$ on defined agar media supplemented with $20 \mu \mathrm{g}$. of adenosine per ml. Adenine auxotrophy has been reported previously in strains of Micrococcus lysodeikticus (Grula, Luk \& Chu, I96I; Kloos \& Schultes, I969); however, it was interesting to note that other strains having different species designations were also auxotrophic. Cultures of $M$. luteus strains СCM I05, СCM 408, СCM 1672 and $M$. flavocyaneus strain CCM85I were received containing both adenine-independent and adenine-dependent cells in ratios (Ade + Ade) of $\mathrm{I} / 9, \mathrm{I} / \mathrm{I} 16, \mathrm{I} / \mathrm{I} 890$ and $\mathrm{I} / 36$, respectively.

Transformation of nutritional markers. DNA isolated from certain strains of Micrococcus flavocyaneus, M. flavus, M. luteus, M. lysodeikticus, M. sodonensis, Sarcina flava, S. lutea, S. subflava, Staphylococcus afermentans and St. flavocyaneus was able to transform auxotrophs of $M$. lysodeikticus to prototrophy (Table I). In all instances, the above strains transformed $M$. lysodeikticus strain ISU at near or equal to homologous, intra-strain frequencies. Variation between DNA preparations from the same strain generally did not exceed $60 \%$ of the mean value.

Adenine-dependent donor strains produced low but significant frequencies of prototrophic transformants when crossed with adenine-dependent Micrococcus lysodeikticus strain IsU. These results would suggest that adenine auxotrophy, in these strains, was the effect of mutation at sites different from the one present in the recipient strain. The very low transformation values obtained may be evidence of mutation in the same adenine locus, though consideration of mutation in different adjacent or closely linked loci, at this point, cannot be excluded. Studies are being pursued to determine the specific enzyme(s) affected in these auxotrophs.

Double transformation of pigment and nutritional markers. It would be of interest to extend genetic studies and test transformation of additional markers with those strains capable of transforming Micrococcus lysodeikticus to prototrophy. One class of mutants that can be identified readily and are produced in high frequencies is pigment mutants. For example, treatment of $M$. lysodeikticus strain ISU (ade ${ }^{+}-\mathrm{I}$ ) with NTG, to obtain auxotrophs used as recipients in this study, resulted in the production of about $2 \%$ pigment mutant, sectored colonies. These included various intensities of yellow, white, pink, orange, chartreuse (similar to the colour of Sarcina lutea strain ATCC 272), and a water-soluble yellow class which dispersed yellow pigment in the surrounding culture medium. Several of these mutants were selected and used as donors in crosses with yellow auxotrophic strains (Table 2). Pigment transformants were scored selectively as double transfromants with prototrophy. In this preliminary study, pigment mutants of $S$. lutea strain ATCC 272 were isolated and used as donors with recipients of $M$. lysodeikticus. The range of different colours produced by treat- 
ment with NTG was similar to that found with M. lysodeikticus. As shown in Table 2, all mutants tested were able to transform yellow auxotrophs of $M$. lysodeikticus strain ISU to the donor colour. The fraction of double pigment-prototroph transformants/ single prototroph transformants for each recipient auxotroph was similar and was approximately $\mathrm{I} / 360$. Additional studies were conducted which showed an increase in the fraction of double transformants/single transformants as the DNA concentration was increased up to saturation levels (Kloos, 1969). Collectively, these results would suggest that the pigment markers are not linked to DNA fragments containing the adenine (ade), histidine (his $D)$, and/or tryptophan $(\operatorname{trp} E)$ loci.

\section{DISCUSSION}

Genetic exchange has been shown to be useful in measuring homology between various bacteria and is usually parallel to the results obtained with nucleic acid hybridization (Dubnau, Smith, Morell \& Marmur, I965; Marmur et al. 1963). The demonstration of genetic exchange between Micrococcus lysodeikticus and certain strains designated as species of the genera Micrococcus, Sarcina, and Staphylococcus implies close genetic relationships among these organisms.

Transformation with such a large array of strains bearing different species and generic designations seems, at first glance, to be most unusual. In particular, nutritional markers are usually transformed only among very closely related organisms (Dubnau et al. 1965). These results, however, are in close agreement with the suggestions of others based on other criteria, classifying these strains as members of a single species, Micrococcus luteus. All strains participating in genetic exchange had very similar GC ratios, $\mathrm{S}$ values, and occurred in Micrococcus subgroup-Ia of the classification of Rosypal et al. (I966).

Sarcina aurantiaca and Micrococcus luteus strain ATCC 398, previously considered by Kocur \& Martinec (I962) to be $M$. luteus strains, failed to produce prototrophic transformants when crossed with $M$. lysodeikticus. These strains had distinctly lower $\mathrm{GC}$ ratios and, according to the above classification, were placed in subgroups $2 c$ and $3 b$, respectively. Micrococcus luteus strain ATCC 398 also has a different menaquinone pattern than that shown for strains in subgroup I $a$ (Jeffries et al. 1968). It should be noted that these strains failed to grow on the defined medium used in transformation experiments and, therefore, any interpretation of negative results should be taken with some caution. Prototrophy with respect to adenine, L-tryptophan, and L-histidine is uncertain in these strains.

The failure of Micrococcus candicans, $M$. citreus, $M$. conglomeratus, $M$. roseus, $M$. rubens and $M$. varians to transform $M$. lysodeikticus was not surprising, as these organisms differ significantly in certain physiological and biochemical features and/or GC ratio (Baird-Parker, I965; Baddiley, Brock, Davison \& Partridge, I968; Bohacek, Kocur \& Martinec, I967; Jeffries et al, I968; Rosypal et al. 1966). Transformation was not expected by strains of Staphylococcus aureus or St. epidermidis either, as members of the genus Staphylococcus as recommended by Evans et al. (1955) are facultative anaerobes and differ in numerous characteristics, including a very low GC ratio (32 to $35 \%$ ) (Auletta \& Kennedy, I966; Baird-Parker, 1965; Garrity, Detrick \& Kennedy, I969; Jeffries et al. 1968). Two additional species designated $M$. radiodurans and Sarcina ureae failed to transform $M$. lysodeikticus. However, there is 
strong evidence that these organisms should be omitted from the family Micrococcaceae (Baird-Parker, 1965; Herndon \& Bott, 1969; Bohacek, Kocur \& Martinec, I967).

I am pleased to acknowledge Mrs Margaret Musselwhite and Mr R. Willis for their technical assistance. I also wish to thank Dr J. B. Evans for his encouragement and advice during this study.

This investigation was supported by the Public Health Service Grant AI 08255-O I from the National Institute of Allergy and Infectious Diseases.

This is paper number 2908 of the Journal Series of the North Carolina State University Agricultural Experiment Station, Raleigh, North Carolina.

\section{REFERENCES}

Adelberg, E. A., Mandel, M. \& Chen, G. C. C. (1965). Optimal conditions for mutagenesis by $N$-methyl- $N$-nitro- $N$-nitrosoguanidine in Escherichia coli $\mathbf{K}$ I2. Biochem. biophys. Res. Commun. I8, 788 .

AulettA, A. E. \& Kennedy, E. R. (I966). Deoxyribonucleic acid base composition of some members of the Micrococcaceae. J. Bact. 92, 28.

Baddiley, J., Brock, J. H., Davison, A. L. \& Partridge, M. D. (I968). The wall composition of micrococci. J. gen. Microbiol. 54, 393.

BAIRD-PARKer, A. C. (1963). A classification of micrococci and staphylococci based on physiological and biochemical tests. J. gen. Microbiol. 30, 409.

BAIRD-PARKER, A. C. (1965). The classification of staphylococci and micrococci from world-wide sources. J. gen. Microbiol. $\mathbf{3 8 ,} 363$.

BohaceK, J., Kocur, M. \& MARTinec, T. (1967). DNA base composition and taxonomy of some micrococci. J. gen. Microbiol. 46, 369.

Dische, Z. (1955). Color reactions of nucleic acid components. In The Nucleic Acids. Ed. by E. Chargaff and J. N. Davidson, vol. I, p. 285. New York and London: Academic Press.

Dubnau, D., Smith, I., Morell, P. \& Marmur, J. (1965). Gene conservation in Bacillus species. I. Conserved genetic and nucleic acid base sequence homologies. Proc. natn. Acad. Sci. U.S.A. 54, $49 \mathrm{I}$.

Evans, J. B., Bradford, W. L. \& Niven, C. F. (1955). Comments concerning the taxonomy of the genera Micrococcus and Staphylococcus. Int. Bull. bact. Nomencl. Taxon. 5, 61.

Fleming, A. (1922). On a remarkable bacteriolytic element found in tissues and secretions. Proc. $R$. Soc. Lond. B 93, 306.

GarRity, F. L., Detrick, B. \& Kennedy, E. R. (1969). Deoxyribonucleic acid base composition in the taxonomy of Staphylococcus. J. Bact. 97, 557.

Grula, E. A., LuK, S. K. \& ChU, Y. C. (196r). Chemically defined medium for growth of Micrococcus lysodeikticus. Can. J. Microbiol. 7, 27.

Herndon, S. E. \& BotT, K. F. (1969). Genetic relationship between Sarcina ureae and members of the genus Bacillus. J. Bact. 97, 6.

Jefrries, L., Cawthorne, M. A., Harris, M., Cook, B. \& Diplock, A. T. (1968). Menaquinone determination in the taxonomy of Micrococcaceae. J. gen. Microbiol. 54, 365.

KLoos, W. E. (1969). Factors affecting transformation of Micrococcus lysodeikticus. J. Bact. 98, I397.

Kloos, W. E. \& Pattee, P. A. (1965). A biochemical characterization of histidine-dependent mutants of Staphylococcus aureus. J. gen. Microbiol. 39, 185.

Kloos, W. E. \& Schultes, L. M. (1969). Transformation in Micrococcus lysodeikticus. J. gen. Microbiol. 55, 307.

Kocur, M. \& Martinec, R. (1962). A taxonomic study of the genus Micrococcus. Folia Fac. Sci. Natur. Univ. Purkynianae Brunensis 3, I.

Kocur, M. \& Martinec, R. (I963). The classification of some violet-pigmented micrococci. J. gen. Microbiol. 32, 185 .

Kocur, M. \& MARTINeC, R. (1965). Some remarks on the classification of micrococci. Int. Bull. bact. Nomencl. Taxon. 15, II3. 
Marmur, J. (I96I). A procedure for the isolation of deoxyribonucleic acid from micro-organisms. J. molec. Biol. 3, 208.

Marmur, J., Falkow, S. \& Mandel, M. (I963). New approaches to bacterial taxonomy. A. Rev. Microbiol. I7, 329.

NAYlor, H. B. \& BURGI, E. (I956). Observations on abortive infection of Micrococcus lysodeikticus with bacteriophage. Virology 2, 577.

Rose, N. E. \& KLoos, W. E. (1969). Transforming system to study genetic relationships of tryptophan mutants of Micrococcus lysodeikticus. Bact. Proc. p. 59.

Rosypal, S. \& Kocur, M. (I963). The taxonomic significance of the oxidation of carbon compounds by different strains of Micrococcus luteus. Antonie van Leeuwenhoek 29, 3 I 3.

Rosypal, S., Rosypalova, A. \& Horejs, J. (1966). The classification of micrococci and staphylococci based on their DNA base composition and Adansonian analysis. J. gen. Microbiol. 44, $28 \mathrm{I}$.

Rosypalova, A., Bohacek, J. \& Rosypal, S. (1966). Deoxyribonucleic acid base composition and taxonomy of violet-pigmented micrococci. Antonie van Leeuwenhoek 32, 105.

SaIto, H. \& Miura, K. (I963). Preparation of transforming deoxyribonucleic acid by phenol treatment. Biochim. biophys. Acta 72, 6r9. 